\title{
Bilingual Education in Western Canada and Chinese Language Minority Students' Self Perceptions of their Citizenship and Ethnicity
}

\author{
伍 洲 Joe Zhou Wu (University of Alberta)
}

\begin{abstract}
Various bilingual education models can either empower or disable minority students according to their goals, structures and human relations (Akkari, 1998). This article presents the findings of a case study on a bilingual program that exists in Western Canada. It examines the structure and contents of the program, and then, based on interviews with a group of Grade 6 bilingual students, discusses their self perceptions of their citizenship, ethnic identity and multicultural thinking.

Résumé : Selon leurs buts, leurs structures et leurs relation humaines, les modèles d'éducation bilingue peuvent donner plus de pouvoir ou en enlever aux élèves des minorités (Akkari, 1998). Cet article fait état des résultats d'une étude de cas réalisée sur un programme bilingue qui existe dans l'Ouest canadien. Nous examinons la structure et les contenus du programme, et ensuite, en nous basant sur des entrevues avec un groupe d'élèves bilingues de sixième année du primaire, nous mettons en évidence leurs perceptions d'eux-mêmes au regard de leur citoyenneté, de leur identité ethnique et de leur pensée sur le multiculturalisme.
\end{abstract}

\section{Multiculturalism as Context}

In the context of multiculturalism as a federal policy in Canada since 1970s, one of the objectives of the Multiculturalism Act was to "preserve and enhance the use of languages other than English or French" (Esses \& Gardner, 2002). In this context, several bilingual programs, Ukrainian, German, Hebrew, Chinese, Arabic, and Spanish bilingual programs appeared in Western Canadian schools. In these programs children receive instructions in an ethnic minority language for about half of their total school instruction time from kindergarten to grade six. Though some of these programs have been in existence for more than two decades, with most keeping steady enrollment or attracting more and more of the student population, very little research has been done on their effectiveness in terms of participants' perceptions of their ethnicity and citizenship.

\section{Theoretical Background}

Every time language learners speak, they are engaged in identity construction and negotiation (Northon, 1997), for self-identity in a minority context is closely related to language environment. Many empirical studies on negative minority self-esteem reveal an unjustified assumption about minority dependence on, and 
conformity to, the ongoing majority definitions (Liebkind, 1989). As the result, subordinated groups often developed negative concepts of themselves and positive attitudes towards the dominant groups, attributing their disadvantaged position internally, i.e. taking individual responsibility for their disadvantaged position. Cummins (1996) states that "human relationships are at the heart of schooling" (p.1) and points out (1993) that students from "dominated" societal groups are either "empowered" or disabled" as a direct result of their interactions with educators in schools. According to him, there are four characteristics that reflect the nature of such interactions, namely, the extent to which (1) the minority students' language and culture are incorporated into the school programs; (2) minority community participation is encouraged as an integral component of the educational program; (3) the pedagogy promotes intrinsic motivation on the part of students to use language actively in order to generate their own knowledge; and (4) professionals involved in assessment become advocates for minority students rather than legitimizing the "problem" as being located in the students.

Bilingual education is generally perceived as a means to empower minority students by acknowledging their home language and culture while building their learning upon the life experience. Bilingual education, however, takes many different forms, each one emphasizing different goals and priorities. Several models of bilingual education have been distinguished, such as transitional bilingual education, enrichment bilingual education, two-way bilingual education and language maintenance bilingual education (Baker, 1996, Akkari, 1998). Transitional bilingual education is the most common type of bilingual education in the United States. Its primary goal is to mainstream minority language students from their native languages to instruction in the dominant language. Under this approach, the students are taught for a transitional period using their native language to ensure that they can keep up in their school subjects, before switching to the dominant language (Baker, 1996, p.178). Akkari (1998) criticizes such model as "transmission-banking" model, with a goal of domestication and perpetuation to keep the social status-quo, and concludes that "most bilingual education programs tended to focus more on disabling than empowering students" (p.117), yet citing Krashen and Biber's study of eight programs across California, Lessow-Hurley concludes that it is "a lot better than nothing" (2000, p.13).

The aim of language maintenance bilingual education is to sustain and enhance the home language among minority students, while phasing in the dominant language. Its purpose is to develop both languages and to preserve the culture of different minority groups (Baker, 1996, p.186). Much of the research into bilingual education has focused on Spanish-speaking students in the United States, however. Considering the wide range of variations among such bilingual programs and their social settings, it is difficult to generalize such research findings. 
This paper focuses on the Chinese Bilingual Program in Western Canada, a significantly different linguistic environment than the United States. First, this paper closely examines the structure and contents of the program to discuss how it serves in different functions for different students, and second, it presents the results of the study of bilingual grade six students' perceptions of their cultural identity, and multiculturalism.

\section{An Examination of the Chinese Bilingual Program}

Canada's minority language bilingual programs started in 1978 when the Ukrainian Bilingual Program was established. Since then, the Arabic, Cree, German, Hebrew, Mandarin Chinese, Polish and Spanish bilingual programs have followed suit. The Chinese Bilingual Program, established in 1981, has become one of the largest bilingual programs in Western Canada. In one city in Alberta, five elementary schools currently collectively enroll over one thousand students from kindergarten to grade 6 . The Chinese bilingual program offers children the same basic academic curriculum content as that of any publicly funded school in Alberta. Fifty percent of instruction time takes place in English and fifty in Mandarin Chinese. Subjects such as social studies, art, health and physical education are taught in Chinese. Others, such as mathematics, science and sometimes music are taught in English, while both Chinese and English language arts are taught.

Separate instructors teach English and Chinese subjects within the Chinese Bilingual Program. Those teaching Chinese subjects are usually new Chinese immigrants with good knowledge of the Chinese language and culture, while most of the English subject instructors are usually native English speakers who present to the class more Canadian culture, but do not know any Chinese.

The Chinese bilingual program attracts mostly the children of first generation immigrants. Most of its students are not native speakers of English before they come to school. In fact, some do not even speak any English. More than half of them do not speak Mandarin, the target language, but instead use one or a variety of different Chinese dialects, such as Cantonese, Phokenese, Toishanese and Shanghainese as their home language. There are also a small number of native English speakers, including some students from other cultural backgrounds, with no knowledge of any Chinese dialects, whose numbers are increasing in last few years. When the children start kindergarten, some begin to learn English or Mandarin as a new language, while others start with two new languages. Newcomers from Asia often join the program at different entry points from kindergarten up. These students usually have more advanced Chinese literacy than local ones; however, their English falls far behind. Due to the variety of different language backgrounds, the program functions in four different ways. It is, firstly, a maintenance program for Chinese minorities to keep their language and cultural heritage. Secondly, it functions as a two way 
bilingual program with both native Chinese and English speakers in the same class. Thirdly, it also serves as a transitional program for new immigrant children to learn English as a second language and to adapt to the Canadian school system. To many, it is an immersion program for learning two new languages at the same time. In general, it is a versatile language program with multiple functions to meet the needs of different students.

As to the students' achievements in other subject areas, Alberta government has been implementing Provincial Achievement Tests each year for students in grades 3 and 6 . These test results show that the Chinese bilingual students' average test scores are consistently higher than the provincial and school district average. The Achievement Tests, including those in Language Arts, are all implemented in English, the language that the students, who come from mostly non-native English speaking families, only spend half of their school time learning. Social Studies, taught mostly in Chinese, is also tested in English on these tests. Students' test scores in this subject are also higher than the provincial average. In fact, a Fraser Institute report ranking Alberta's elementary schools placed one of the city's elementary schools, in which 80 percent of the students are in the Chinese bilingual program, No. 41 among 201 in the municipal area. A local newspaper commented on the school's ranking as a "hidden surprise" since the school is located in a lower middle class neighborhood and a typical parent at this school has completed just 13 years of formal education (Simons, 2002).

In fact, most of the students attending the Chinese Bilingual Program (CBP) do not live in the immediate neighborhood. They are mostly bused to the schools from several nearby neighborhoods. When the sites were chosen for setting up new bilingual schools, those that were facing closure due to a lack of new perspective students in older neighbourhoods were often selected. This is an example of bilingual programs, which do not necessarily cost extra public funding, salvaging dwindling schools. The economic status of the bilingual children's families varies. The majority of these students' families are not well established in society and many belong to lower-middle class.

\section{The Bilingual Students’ Perception of Language Learning and Identity}

One of the most important goals of bilingual education is the empowerment of minority students through recognizing their language and culture while improving their self-esteem. This study is designed to achieve further understanding of the role of the Chinese bilingual education with respect to students' self esteem and cultural identity. Within a qualitative paradigm, fourteen Chinese bilingual children from a grade 6 elementary class participated individually in a semi-structured interview. Among these children, twelve participants were Canadian born and two were born in China. The interviews 
were conducted in English, the language that most the students felt more comfortable with at their grade level.

\section{Negative and Positive Experiences of Speaking Chinese}

When the bilingual participants were asked about how they were treated speaking Chinese in the Canadian society, many pointed out both negative and positive experiences. Examples of negative experiences include being teased about speaking "gibberish Chinese" and being insulted by a neighbor who said "Chinese sucks". A boy remembered an incident on the bus when his father was teased for speaking Cantonese. Another boy claimed that other students often insulted him because of his Chinese background when he was in another school. A girl reported she had occasionally felt put down by other students at the school and made to feel that Chinese people were bad. While pointing out these incidents, many could also acknowledge experiences of being respected by many people because they could speak a different language. One boy remembered that in Scouts, many of his friends were impressed by his ability to speak other languages and asked him questions. One girl, who reported being occasionally teased and called dumb by non-Chinese students at her school, noted that despite this some other people thought she was cool because she could speak another language and were jealous of her. A girl indicated that her English teacher made her feel very good about knowing different languages. She imagined she would try to make other newcomers feel comfortable by being kind to them. Another girl felt that she treated people better if they spoke another language and she had befriended a Ukrainian girl once. Most of them said that they would treat other people the same, no matter what language they spoke.

\section{Understanding of Multiculturalism and Multicultural society}

All the bilingual students interviewed agreed that Canada was a multicultural country. They explained their understandings of what a multicultural country was, and what it meant to them in different ways. One student thought that in a multicultural society "one can see different things and shop in different types of stores". Many pointed out that a multicultural country was one where immigrants of all countries, with all sorts of different cultures could come to. One has mentioned that all people were equal and were treated "evenly". A student observed that "a multicultural country is one that lots of people come here and have peace". A multicultural country was also understood as a country where different people could live together and didn't have to feel too different. Some emphasized that multiculturalism meant sharing their cultures with others.

\section{Feeling of Belonging}

On whether they believed that they could fit into Canadian society, all participants answered affirmatively. Some indicated that they fit pretty well into 
Canadian multicultural society because they feel very comfortable here. The participants constantly repeated that they could get along with other people, including those from different backgrounds. A boy stated that he had Canadian friends but still did Chinese things. Some also answered that they fit in because they know different languages and cultures. One student felt good being in a multicultural country because there were lots of other kids like him who were from a different culture. As a result, he would be recognized as a good, maybe even special, person. Another student felt that multiculturalism referred to all the different sorts of people who populate Canada: Chinese, Jewish, African and many different groups. The CBP had helped her to understand Canada as a multicultural country because everyone has the opportunity to learn many different languages.

\section{Sense of Ethnicity}

All the students treated their ethnic identity positively. They felt positive about being Chinese, and at the same time, all tried to attain balance by recognizing their Canadian side. Factors used by the bilingual children to determine their identities were their language, culture, birthplace and their parents' ethnic origin. For example, one girl refers to herself as a Cantonese Canadian because she spoke Cantonese most of the time. A boy described himself as Chinese Canadian because he was born in Canada but his culture and first language were Chinese. One elaborated "My blood is Chinese but I am Canadian." Another said: "Chinese is the true part that's in me because I am a Chinese person, but I live in Canada so I am a part of both." In general, these statements did not give clear indication on whether they place more importance on their Chinese or Canadian side. It seems none of them overemphasized either side.

\section{Role of Bilingual Education in Understanding Chinese Culture}

With respect to their understanding of Chinese culture, many stated that if they didn't attend the program, they might forget how to speak their native language, or would not be able to learn the Chinese language. One girl, who moved from a mainstream school to the bilingual program, felt that the program had helped her learn and value her own culture because before she only thought about the English culture. One student valued the fact that the program helped him to learn the history of China and how it changed. These opportunities to learn Chinese history were an essential part to him in understanding his Chinese roots. Others acknowledged that the program had helped them understand Chinese culture by celebrating their own holidays. Students also discussed the role of the Chinese Bilingual Program in teaching them multicultural thinking. One explained that the program had helped him understand multiculturalism because it had taught him about Chinese culture, and to understand that different languages could fit into Canada. A boy noted that the program had helped him to be aware of how other immigrants felt about their cultures after becoming aware of his own culture. Other comments include "The Chinese Bilingual Program has allowed 
me to learn about other cultures, to respect them and to interact with other cultures."

\section{Discussion}

Participants' responses to the interview questions reflect an empowering experience through bilingual education. Their comments on their negative experiences of using their mother tongue indicate that they did encounter racism. Negative experiences inevitably affected their sense of who they are and how they relate to the world. In spite of their negative experiences, the children commented that they were proud of being able to speak their language and felt quite confident of their ethnic identity. To them, their language was a valuable asset that should be respected and even envied upon. Some even expressed that they felt special being Chinese people. There were no indications of feeling ashamed of or denial of their ethnicity. Such confidence can also be seen in how they saw Canada as a multicultural society and how they felt about themselves as being part of it. They listed diversity, equality, freedom of being different, and sharing among cultures as the characteristics of a multicultural society. These grade six children understood such complex concepts through their own life experiences and they strongly believed that they could fit in such a multicultural society.

Participants' comments illustrate patterns of connections between their positive attitudes towards their own language, culture, ethnic identity and their experiences in the bilingual program. Through the experience in the program, they learned to value their language and culture. Such understandings also projected into their understandings and sympathy of other cultures and their appreciation of multiculturalism. The Chinese bilingual students did not seem to have undergone pressure from forced assimilation and there were no indications that they saw themselves as inferior.

The cultural component is essential to the Chinese bilingual program. The program is the confirmation of the students' home culture. This is how it empowers the Chinese minority students in a society where minority values are mostly silenced through cultural dominance. Bilingual education in Western Canada is changing its name from "Heritage Language Programs" to "International Language Programs". The change reflects current educational efforts to prepare the young generation for participation in the global community and economy; however, bilingual programs' important function of cultural confirmation cannot be altered or diluted. Empowering young people, nourishing positive self-identity, and supporting minorities to become full citizens of Canada's multicultural society are the essence of the program. 


\section{References}

Akkari, A. (1998). Bilingual education: Beyond linguistic instrumentalization. Bilingual Research Journal, 22, 103-125.

Baker, C. (1996). Foundations of Bilingual Education and Bilingualism. (2nd ed). Sydney: Multilingual Matters.

Cummins, J. (1993). "Empowering minority students: A framework for intervention". In L. Weis \& M. Fine (Ed.), Beyond silenced voices: Class, race and gender in the United States schools (pp. 101-139). New York: SUNY Press.

Cummins, J. (1996). Negotiating identities: Education for empowerment in a diverse society. Ontario, CA: Califormia Association for Bilingual Education.

Esses, V.M. \& Gardner, R.C. (1996). "Multiculturalism in Canada: Context and current status." In V. M. Esses \& R.C. Gardner (Eds), Ethnic relations in a multicultural society. Special issue of Canadian Journal of Behavioural Science, 28 (3) [journal online]; available from <http://www.cpa.ca/cjbsnew/1996/vol28-3.html>; Internet; accessed 11 Februrary 2005.

Lessow-Hurley, J. (2000). The foundations of dual language instruction. New York: Longman.

Liebkind, K. (1989). The identity of a Minority. Journal of Multilingual and Multicultural Development, 10, 47-57.

Norton, B. (1998). Language, identity, and the ownership of English. TESOL Quarterly, 31 (1), 409-429.

Simons, P. (2002). Edmonton Journal, June 11.

30 Canadian and International Education Vol. 34 no. 1 - June 2005 